\title{
Mucosal healing with anti-TNF antibodies
}

Chevaux, Jean-Baptiste ; Vavricka, Stephan R ; Rogler, Gerhard ; Lakatos, Peter L ; Schoepfer, Alain ; Peyrin-Biroulet, Laurent

\begin{abstract}
Nowadays, mucosal healing is regarded as a major end point in clinical trials and is increasingly used in clinical practice for the management of patients with inflammatory bowel disease. The definition of mucosal healing varies across studies and validated endoscopic scoring indices are still lacking. The advent of anti-tumor necrosis factor agents has changed the way of treating inflammatory bowel disease and high rates of induction and maintenance of mucosal healing can be achieved with this drug class. Mucosal healing is desirable as it may change the natural course of the disease by decreasing surgery and hospitalization rates in both ulcerative colitis and Crohn's disease.
\end{abstract}

DOI: https://doi.org/10.1159/000341957

Posted at the Zurich Open Repository and Archive, University of Zurich

ZORA URL: https://doi.org/10.5167/uzh-76211

Journal Article

Accepted Version

Originally published at:

Chevaux, Jean-Baptiste; Vavricka, Stephan R; Rogler, Gerhard; Lakatos, Peter L; Schoepfer, Alain; Peyrin-Biroulet, Laurent (2012). Mucosal healing with anti-TNF antibodies. Digestion, 86(Suppl. 1):1622.

DOI: https://doi.org/10.1159/000341957 


\section{Mucosal healing with anti-TNF antibodies}

Jean-Baptiste Chevaux ${ }^{1}$, Stephan R. Vavricka ${ }^{2,3}$, Gerhard Rogler ${ }^{3}$, Peter L. Lakatos ${ }^{4}$, Alain Schöpfer ${ }^{5}$, Laurent Peyrin-Biroulet ${ }^{1}$

1Department of Hepato-Gastroenterology, Nancy University Hospital, Université de Lorraine, Vandoeuvre-les-Nancy, France.

${ }^{2}$ Triemlispital Zurich, Division of Gastroenterology and Hepatology, Zurich, Switzerland

${ }^{3}$ Division of Gastroenterology \& Hepatology, University Hospital of Zürich, Zürich, Switzerland

${ }^{4} 1^{\text {st }}$ Department of Medicine, Semmelweis University, Budapest, Hungary

${ }^{5}$ Division of Gastroenterology and Hepatology, Centre Hospitalier Universitaire Vaudois / CHUV, Lausanne, Switzerland

Correspondence:

Prof. Laurent Peyrin-Biroulet, MD, PhD

Department of Hepato-Gastroenterology, Nancy University Hospital, Université de Lorraine Allée du Morvan, 54511 Vandoeuvre-les-Nancy, France.

Phone : +33 3831533 63/Fax : +33 383133633 
Email : peyrinbiroulet@gmail.com

Disclosures: L.P.B., consulting and lecture fees from Abbott and Merck; J.B.C. declares no conflicts of interest.

Grant support: This research was supported by grants from the Swiss National Science Foundation (SNF) to AS (Grant No. 32003B_135665/1), to SRV (Grant No 320000-114009/3 and 32473B_135694/1), by the Zurich Center for Integrative Human Physiology (ZIHP) of the University of Zurich, and the Swiss IBD Cohort (Grant No. 3347CO-108792).

Key words: Mucosal healing, Crohn's disease, ulcerative colitis, anti-TNF 


\begin{abstract}
Nowadays, mucosal healing is regarded as a major endpoint in clinical trials and is increasingly used in the management of patients with inflammatory bowel disease (IBD) in clinical practice. Definition of mucosal healing varied across studies and validated endoscopic scoring indexes are still lacking. The advent of anti-Tumor Necrosis Factor agents has changed the way of treating IBD and high rates of induction and maintenance of mucosal healing can be achieved with this drug class. Mucosal healing is desirable as it may change the natural course of the disease by decreasing surgery and hospitalization rates in both ulcerative colitis and Crohn's disease.
\end{abstract}


Initial lack of correlation between mucosal healing $(\mathrm{MH})$ and clinical remission in inflammatory bowel diseases (IBD) patients led the clinician to abandon this concept [1]. The advent of anti-Tumor Necrosis Factor (TNF) agents has changed the way of treating IBD. Anti-TNF therapy allows rapid symptoms improvement but also mucosal healing (MH) [2]. Accumulating evidence indicates that MH may change the course of both Crohn's disease (CD) and ulcerative colitis (UC) [3-5]. Accordingly, $\mathrm{MH}$ is now regarded as an important treatment end point in clinical trials and is increasingly used in clinical management of IBD [6].

After discussing available definitions of $\mathrm{MH}$, we will review the efficacy of anti-TNF antibodies to induce and maintain $\mathrm{MH}$ before highlighting the positive impact of $\mathrm{MH}$ on longterm outcomes in IBD.

\section{DEFINING MUCOSAL HEALING}

$\mathrm{MH}$ is usually assessed by ileocolonoscopy or proctosigmoidoscopy in CD and UC, respectively. However, the definition of $\mathrm{MH}$ varies across studies and there is no validated definition of $\mathrm{MH}$ or endoscopic remission in IBD [7,8]. Various definitions of $\mathrm{MH}$ have been used in CD in clinical trials and referral center-based studies (Table 1 and 2) : absence of mucosal ulcerations and ulcers $[9,10]$ or absence of ulcerations at follow-up endoscopy in patients who had ulcerations present at baseline ileocolonoscopy [11]. Definition of $\mathrm{MH}$ in $\mathrm{CD}$ as the total disappearance of ulcers is simple in clinical practice, but this binary statement does not take into account patients with evidence of $\mathrm{MH}$ under treatment with few lesions left such as erosions. In UC, the International Organization of IBD made a consensus in 2007 to define $\mathrm{MH}$ : absence of friability, blood, erosions and ulcers in all visualized segments of the 
gut mucosa [12]. Presence of only abnormal vascular pattern is still compatible with $\mathrm{MH}$ according to panel experts [12].

For the assessment of $\mathrm{MH}$, clinicians require reproducible and validated scoring indices of disease activity (Table 1) [12]. There are mainly three endoscopic disease activity indexes used in clinical trials for CD: the Crohn's Disease Endoscopic Index of Severity (CDEIS) [13], the Simple Endoscopic Score for Crohn's Disease (SES-CD) [14] and the Rutgeerts score [15]. The CDEIS is a prospectively built scoring index, based on elementary CD lesions and percentage of involvement of different ileocolonic segments [13]. The CDEIS, considered as the gold standard scoring index, is regarded as complex and this limits its usefulness in clinical practice, with use largely restricted to the clinical trial setting. A simple index, the SES-CD has been developed and correlates well with the CDEIS [14]. SESCD involves four variables: ulcer sizes, the extent of ulcerated surface, extend of affected surface and stenosis in five segments bowel. However, the SES-CD is not validated. For both indices, there is no validated cut-off value for defining endoscopic remission, response or MH. Two cut-offs defining endoscopic remission (CDEIS <6) and complete MH (CDEIS <4) have been proposed [16].

The Rutgeerts score is used in the postoperative setting to determine the presence and severity of endoscopic disease recurrence in the neoterminal ileum after ileal or ileocolonic resection [9]. Scoring is based on the presence of aphthous lesions, inflamed mucosa, nodules, narrowing and ranges from i0 to i4 accordingly [9]. Most of clinical trials have used i2 as cutoff to define endoscopic recurrence. However, the Rutgeerts score still lacks validation.

In the small bowel, capsule endoscopy is increasingly used to assess severity of CD [17]. Specific disease activity indexes have been developed, but still await validation before using them in clinical trials and/or clinical practice [18]. 
In UC, the first index was developed by Truelove and Witts in a placebo-controlled trial on cortisone treatment [19]. Thereafter, several endoscopic system scoring systems have been developed (modified Baron score [20], Mayo endoscopic subscore [21]...) but none of them have been fully validated (Table 2). Recently Travis et al. [22] have proposed a new endoscopic score, namely the Ulcerative Colitis Endoscopic Index of Severity (UCEIS). Development of this index was made in two phases in order to assess intra- and interindividual variation in the overall endoscopic assessment of severity [22]. One of the major differences with the Mayo endoscopic subscore is the exclusion of the item "friability" from the endoscopic description of severity [22]. This score is composed of the following items: vascular pattern, bleeding, erosions and ulcers; it should be largely used in clinical trials and clinical practice in the future once validated independly [22].

INDUCTION AND MAINTENANCE OF MUCOSAL HEALING WITH ANTI-TNF AGENTS

\section{Induction}

In the ACCENT 1 [23] trial, a randomized controlled trial evaluating the efficacy of infliximab for the treatment of refractory active CD, an endoscopic substudy [10] of 99 patients was performed. MH was observed at week 10 in $29 \%$ of patients (13/45) who had received induction therapy with three infusions of infliximab compared with $3 \%$ patients $(1 / 29, p=0.006)$ who received only one infusion at baseline [10]. Systematic maintenance therapy with infliximab therapy every 8 weeks allowed MH in $44 \%(16 / 36)$ of CD patients at weeks 54 compared to $18 \%(4 / 22, \mathrm{p}=0.041)$ in patients treated episodically [10]. In the SONIC trial, which compared infliximab, azathioprine monotherapy and combined infliximab 
and azathioprine therapy for active luminal $\mathrm{CD}, \mathrm{MH}$ was significantly higher in the combined $\operatorname{arm}(44 \%, \mathrm{p}<0.001)$ at week $26[24]$.

The MUSIC trial is an open-label study that assessed the ability of certolizumab pegol to induce $\mathrm{MH}$ at 10 weeks in $89 \mathrm{CD}$ patients with active diseases [16]. Induction therapy consisted in subcutaneous injection at weeks 0,2 and 4 followed by one injection at week 8 . At 10 weeks, endoscopic remission (defined as CDEIS < 6) was seen in $42 \%$ but MH (defined as absence of ulcers) was seen in only $5 \%$ of patients [16]. The EXTEND trial, evaluating the efficacy of adalimumab for the treatment of moderate to severe active ileocolonic CD, has used $\mathrm{MH}$ at week 12 as a primary endpoint [9]. $135 \mathrm{CD}$ patients have received 160 then 80 mg induction therapy at weeks 0 and 2, and were then randomized at week 4 to blinded maintenance therapy with $40 \mathrm{mg}$ adalimumab every other week or placebo through week 52 . Primary endpoint was achieved in $27 \%$ (17/62) of the adalimumab arm compared with $13 \%$ $(8 / 61)$ of placebo-treated patients $(\mathrm{p}=0.056)$ [9]. At week 52, rates of $\mathrm{MH}$ were $24 \%$ and 0 , respectively ( $\mathrm{p}<0.001)$. Remission rates, based on CDEIS, were $52 \%$ for adalimumab and $28 \%$ for placebo at week $12(\mathrm{p}=0.06)$ and $28 \%$ and $3 \%$, respectively, at week $52(\mathrm{p}<0.01)$ [9]. (Figure 1)

In the ACT 1 and ACT 2 trials, [25,26] infliximab or placebo were administered intravenously in 364 (in each study) patients with moderate-to-severe refractory UC. Induction therapy with infliximab $5 \mathrm{mg} / \mathrm{kg}$ given at weeks 0,2 and 6 resulted at week 8 in $\mathrm{MH}$ in $62 \%$ of patients in ACT 1 trial and $60.3 \%$ of patients in ACT 2 study compared with $33.9 \%$ and $30.9 \%$ in the placebo groups of each study ( $p<0.001$ in both trials) $[25,26]$. A small, open-label study involving 20 patients has evaluated efficacy of adalimumab in patients with endoscopic evidence of moderate to severe active, refractory UC [27]. Induction treatment with adalimumab $160 \mathrm{mg}$ at week $0,80 \mathrm{mg}$ at week 2 and $40 \mathrm{mg}$ every other week resulted in $\mathrm{MH}$ in 30\% of patients at week 8 [27]. Finally in the ULTRA 2 trial [28], a 
randomized, double-blind, placebo-controlled trial, efficacy of adalimumab in UC patients for induction was evaluated [28]. At week $8, \mathrm{MH}$ was achieved in $41.1 \%$ of patients receiving adalimumab and $31.7 \%$ of patients receiving placebo $(\mathrm{p}=0.032)$ [28]. (Figure 2)

\section{Maintenance}

Anti-TNF agents have also demonstrated efficacy in maintaining MH in IBD patients. In the ACCENT 1 trial [23], scheduled treatment strategy with infliximab demonstrated sustained $\mathrm{MH}$ in almost $50 \%$ of treated patients at 1 year. Moreover, a greater proportion of patients with scheduled treatment achieved complete $\mathrm{MH}$ at week 54 compared to the episodic group (50\% vs. 7\%, p =0.007) [29]. D'Haens et al. [30], demonstrated that early induction therapy with infliximab combined with azathioprine maintenance therapy resulted in a greater rate of $\mathrm{MH}$ at 14 weeks $(73.1 \%)$ compared to the step-up approach with steroids and azathioprine $(30,4 \%, \mathrm{p}=0.0028)$ [30]. In the EXTEND trial, a significant difference was observed in terms of $\mathrm{MH}$ at 1 year in the maintenance therapy group with adalimumab compared to the placebo group (24\% vs. 0\%, respectively) [9]. (Figure 1)

In the postoperative setting, anti-TNF also allows maintenance of $\mathrm{MH}$. In a randomized study, Regueiro et al. studied [24] patients with CD who had undergone ileocolonic resection to receive intravenous infliximab, administered within 4 weeks of surgery and continued for 1 year, or placebo [31]. Rate of recurrence (Rutgeerts score $\geq i 2$ ) at 1 year was significantly lower in the infliximab group $(9.1 \%)$ compared with the placebo group $(84.6 \%, \mathrm{p}=0.0006)$ [31].

In UC, in the ACT 1 trial scheduled maintenance therapy with infliximab $5 \mathrm{mg} / \mathrm{kg}$ every 8 weeks resulted in $\mathrm{MH}$ in $45.5 \%$ of patients compared with $18.2 \%(\mathrm{p}<0.001)$ in the placebo group at week 54 [25]. In the ULTRA 2 trial, MH in UC patients under adalimumab 
every other week was achieved at week 52 in $25 \%$ and $15.4 \%$ in the active arm and placebo group, respectively $(\mathrm{p}=0.032)[28]$. (Figure 2)

\section{IMPACT OF MUCOSAL HEALING ON THE DISEASE COURSE}

\section{Clinical response/remission}

In the ACCENT 1 trial, patients who achieved $\mathrm{MH}$ with infliximab had a longer relapse-free than those without MH [32]. Moreover, at week 54, a longer duration of clinical remission was observed in the complete $\mathrm{MH}$ group (20 weeks) compared to patients without complete MH (4 weeks) [32]. In a substudy of the ACCENT 1 trial, MH at weeks 10 and 54 was associated with higher clinical remission rates through week 54 although these results were not statistically significant [29].

A substudy of the "step-up/top-down" trial focused on the value of the endoscopic assessment after 2 years of treatment on clinical outcomes at years 3 and 4 . MH (defined as a SES-CD score of zero) at 2 years predicted stable sustained clinical remission in the following 2 years in $68 \%$ of the patients versus $35 \%$ of patients $(p=0.004)$ with endoscopic evidence of persistent disease activity (defined as a SES-CD score from 2 to 9) [33]. In a large retrospective cohort study involving 214 CD patients under anti-TNF therapy, Schnitzler et al. evaluated the impact of $\mathrm{MH}$ on long-term outcomes [11]. At 5 years, clinical remission was maintained in $65 \%(83 / 128)$ of patients with $\mathrm{MH}$ compared with $40 \%(34 / 86)$ of patients who did not achieve MH $(\mathrm{p}=0.0004)[11]$.

Rutgeerts score has become the gold standard to evaluate CD postoperative recurrence as severity of endoscopic lesions at 1 year has been demonstrated to be predictive of clinical recurrence [15]. A total of $89 \mathrm{CD}$ patients who had been treated by ileal resection were 
included in a prospective cohort study [15]. Three years after surgery, the endoscopic recurrence rate was $85 \%$ and symptomatic recurrence occurred in 34\% [15]. Endoscopic disease often recurs after infliximab is stopped. In a prospective cohort study of 12 consecutive patients under postoperative infliximab regimen, treatment was stopped 3 years after surgery. Discontinuation of infliximab resulted in endoscopic recurrence at 4 months in 10 of 12 patients $(83 \%)$ [34].

In UC, similar findings were reported in a landmark study from 1966 [35]. Indeed $40 \%$ of UC patients who achieved $\mathrm{MH}$ after acute treatment with oral and rectal corticosteroids remained asymptomatic during a 1-year follow up [35], whereas only $18 \%$ of patients who did not achieve $\mathrm{MH}$ after treatment remained asymptomatic during the same period [35]. In the ACT 1 and ACT 2 trials [25,26], the proportion of patients in clinical remission at week 30 of therapy was fourfold greater for patients with $\mathrm{MH}$ at week 8 (48.3\% vs. $9.5 \%$, respectively).

Overall, these findings suggest that $\mathrm{MH}$ is associated with both higher clinical response and lower relapse rates in both CD and UC [36].

\section{Hospitalizations}

In the endoscopic substudy of the ACCENT I trial, patients achieving $\mathrm{MH}$ at both weeks 10 and 54 needed less CD-related hospitalizations (0\%) compared to those with $\mathrm{MH}$ at only one of both visits $(18.8 \%)$ or with no healing at either visit (28\%) [29]. In a retrospective single centre cohort study evaluating the long-term outcome of infliximab in 214 patients with $\mathrm{CD}$, patients who achieved $\mathrm{MH}$ needed hospitalization less frequently compared to patients who did not (42.2\% vs. $59.3 \%$, respectively, $\mathrm{p}=0.0018)$ [11]. 
In UC, Ardizzone et al. showed that no MH after first course of corticosteroid therapy was associated with a more aggressive disease course [37]. Indeed, after multivariate analysis, lack of MH was the only factor associated with negative outcomes at 5 years, including hospitalization (HR, 3.634; 95\% CI, 1.556-8.485; P = 0.0029) [37].

Thus, $\mathrm{MH}$ is associated with lower hospitalization rates in both UC and CD [36].

\section{Surgery}

Extensive and deep ulcerations in CD patients predicted a more aggressive clinical course with increased rates of penetrating complications and surgery [38]. In a retrospective single center cohort study, Schnitzler et al. found that patients who had MH under infliximab regimen needed less abdominal surgeries than those who did not achieve $\mathrm{MH}(14.1 \%$ [12/89] vs. $38.4 \%$ [33/86], respectively, $\mathrm{P}<0.0001)$ [11]. In a Norwegian population-based cohort study involving 458 IBD patients a greater proportion of CD patients (11\% [6/53]) who achieved MH at 1 year were able to avoid surgical resection by 5 years compared with $20 \%$ $(18 / 88)$ of patients without MH at 1 year $(\mathrm{p}=0.10)$ [39]. Regarding UC, $2 \%$ of patients with $\mathrm{MH}$ at 1 year needed a surgical resection by 5 years compared to $7 \%$ of patients without $\mathrm{MH}$ $(\mathrm{p}=0.02)[39]$.

In a retrospective single center study, Ferrante et al. [40] demonstrated that a longer colectomy-free survival was observed among UC patients who achieved $\mathrm{MH}$ (defined as Mayo endoscopic subscore of 0 or 1 ) at week 4 or 10.

Hence, MH is associated with a reduced need for surgery in both CD and UC [36]. 
In a case-control study of 68 UC patients and 136 matched controls, histological inflammation score was the only independent risk factor for the development of colorectal neoplasia (OR 4.69, 95\% CI, 2.10-10.48; P < 0.001) [41].

In a subsequent study, the same authors showed that macroscopically normal endoscopic findings returned the 5-year cancer risk to that of the general population (OR 0.38 , 95\% CI, 0.19-0.73; $\mathrm{P}=0.003$ ) [42]. Rubin et al. also demonstrated a higher risk of cancer and dysplasia in UC patients with a higher inflammatory activity score (OR 2.73, 95\% CI, 1.445.18; $\mathrm{P}=0.002$ ) [43]. Gupta et al. confirmed that histological inflammation over time was associated with the progression towards advanced neoplasia in UC (Hazard ratio 3, 95\% CI, 1.4-6.3) [44].

$\mathrm{MH}$ is thus associated with a lower risk of colorectal cancer in UC, whereas such data are lacking in CD [36]. 


\section{CONCLUSION}

The definition of $\mathrm{MH}$ is still debated and no formal definition has been universally accepted. Except for CDEIS, all endoscopic indexes are still lacking validation in CD and UC. Anti-TNF therapy is the most potent drug class to induce and maintain $\mathrm{MH}$ in IBD. MH may change the natural course of the disease by decreasing the need for surgery and reducing hospitalization rates in both UC and CD. Mucosal healing may also prevent the development of long-term disease complications, such as bowel damage in CD and colorectal cancer in UC. Schnitzler et al. [11] have shown that MH predicts long-term outcome with maintenance therapy with infliximab in CD. The need for surgery was significantly different between the groups with and without $\mathrm{MH}(14 \%$ and $38.4 \%$, respectively, $\mathrm{P}<0.0001)$. Interestingly, there was no difference between the groups with complete and partial $\mathrm{MH}$ (14\% vs. $14.1 \%$, respectively). Hence, the degree of $\mathrm{MH}$ that is required to change the disease course will require further investigation. 
Table 1. Main clinical trials with anti-TNF agents using mucosal healing (MH) as a primary or secondary endpoint in CD.

\begin{tabular}{|c|c|c|c|c|}
\hline $\begin{array}{c}\text { Study name } \\
\text { (Ref.) }\end{array}$ & Study design & $\begin{array}{c}\text { Anti-TNF } \\
\text { agent }\end{array}$ & $\begin{array}{c}\text { Endoscopic } \\
\text { index used }\end{array}$ & MH definition \\
\hline $\begin{array}{c}\text { ACCENT 1 } \\
\text { endoscopic } \\
\text { substudy [10] }\end{array}$ & $\begin{array}{c}\text { Multicenter, } \\
\text { randomized, } \\
\text { doubleblind } \\
\text { controlled study }\end{array}$ & Infliximab & CDEIS & $\begin{array}{c}\text { Complete absence of } \\
\text { mucosal ulcerations } \\
\text { that were observed at } \\
\text { baseline }\end{array}$ \\
\hline SONIC [24] & $\begin{array}{c}\text { Multicenter, } \\
\text { randomized, } \\
\text { double blind } \\
\text { controlled study }\end{array}$ & Infliximab & $\begin{array}{c}\text { No score used; } \\
\text { only descriptive } \\
\text { evaluation }\end{array}$ & $\begin{array}{c}\text { Complete absence of } \\
\text { mucosal ulceration in } \\
\text { the colon and } \\
\text { terminal ileum }\end{array}$ \\
\hline D'Haens et \\
al. [30] & $\begin{array}{c}\text { Multicenter, open- } \\
\text { label, randomized } \\
\text { study }\end{array}$ & Infliximab & SES-CD & No ulcers \\
\hline MUSIC [16] & $\begin{array}{c}\text { Multicenter, open- } \\
\text { label study }\end{array}$ & Certolizumab & CDEIS & $\begin{array}{c}\text { Absence of ulcers } \\
\text { Endoscopic remission } \\
\text { defined as CDEIS <6 }\end{array}$ \\
\hline EXTEND [9] & $\begin{array}{c}\text { Randomized, } \\
\text { double blind, } \\
\text { placebo-controlled } \\
\text { study }\end{array}$ & Adalimumab & SES-CD & Absence of mucosal \\
ulceration
\end{tabular}


Table 2. Main clinical trials with anti-TNF agents using mucosal healing $(\mathrm{MH})$ as a secondary endpoint in UC.

\begin{tabular}{|c|c|c|c|c|}
\hline $\begin{array}{c}\text { Study name } \\
\text { (Ref.) }\end{array}$ & Study design & $\begin{array}{c}\text { Anti-TNF } \\
\text { agent }\end{array}$ & $\begin{array}{c}\text { Endoscopic } \\
\text { index used }\end{array}$ & MH definition \\
\hline ACT 1 [25] & $\begin{array}{c}\text { Multicenter, } \\
\text { randomized, } \\
\text { double-blind, } \\
\text { placebo-controlled } \\
\text { study }\end{array}$ & Infliximab & $\begin{array}{c}\text { Mayo } \\
\text { endoscopic } \\
\text { subscore }\end{array}$ & $\begin{array}{c}\text { Absolute subscore for } \\
\text { endoscopy of 0 or 1 }\end{array}$ \\
\hline $\begin{array}{c}\text { Afif et al. } \\
\text { [27] }\end{array}$ & $\begin{array}{c}\text { Multicenter, open- } \\
\text { label study }\end{array}$ & Adalimumab & $\begin{array}{c}\text { Mayo } \\
\text { endoscopic } \\
\text { subscore }\end{array}$ & $\begin{array}{c}\text { Decrease in } \\
\text { endoscopic subscore } \\
\text { from 2 or 3 at } \\
\text { baseline to 0 or 1 }\end{array}$ \\
\hline ULTRA 2 & $\begin{array}{c}\text { Multicenter, } \\
\text { randomized, } \\
\text { double-blind, } \\
\text { placebo-controlled } \\
\text { trial }\end{array}$ & Adalimumab & $\begin{array}{c}\text { Mayo } \\
\text { endoscopic } \\
\text { subscore }\end{array}$ & $\begin{array}{c}\text { Endoscopy subscore } \\
\text { 0 or 1 }\end{array}$ \\
\hline
\end{tabular}


Figure 1. Number of CD patients achieving MH $(\%)$ in clinical trials with anti-TNF agents.

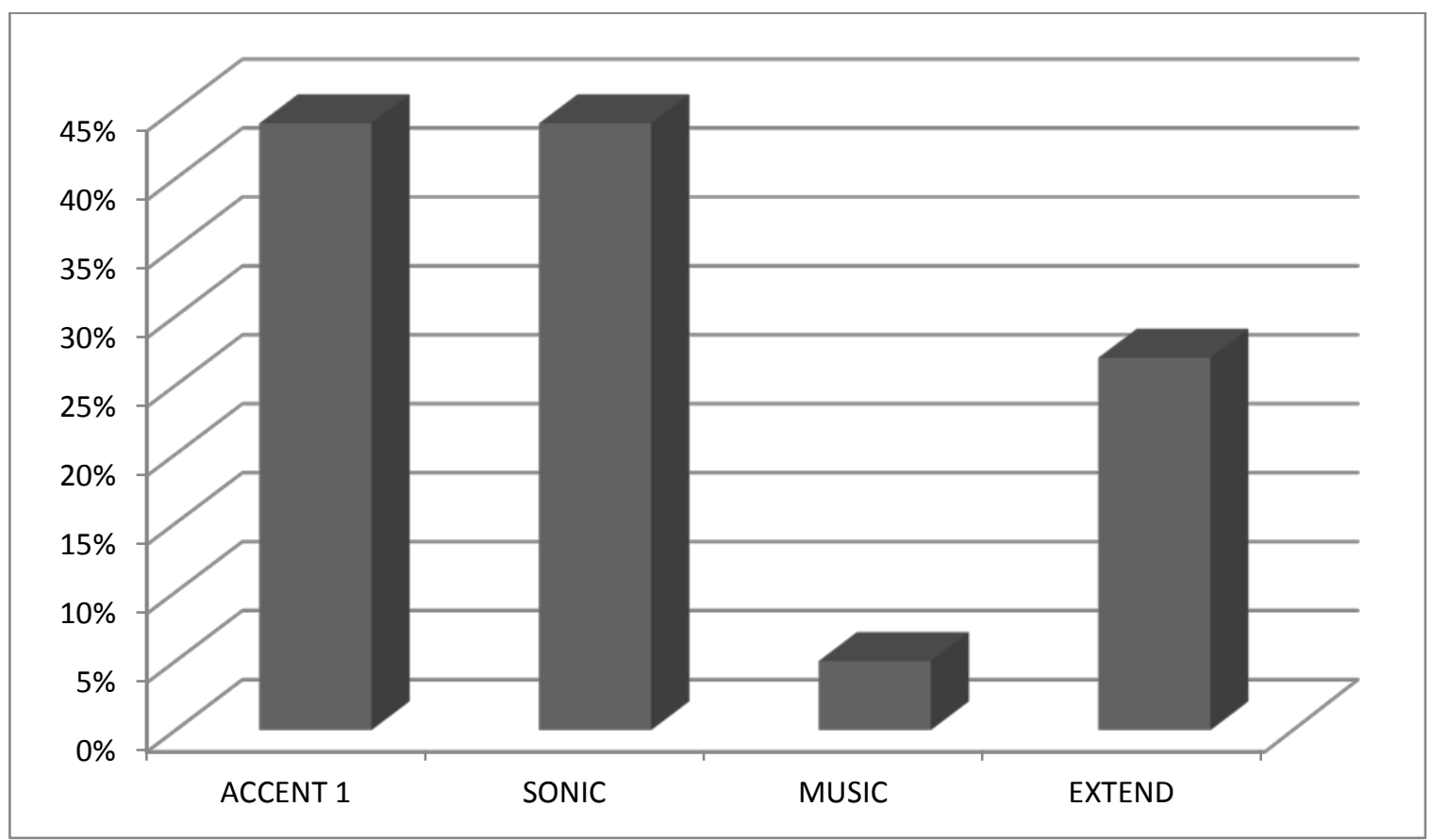


Figure 2. Number of UC patients achieving MH (\%) in clinical trials with anti-TNF agents.

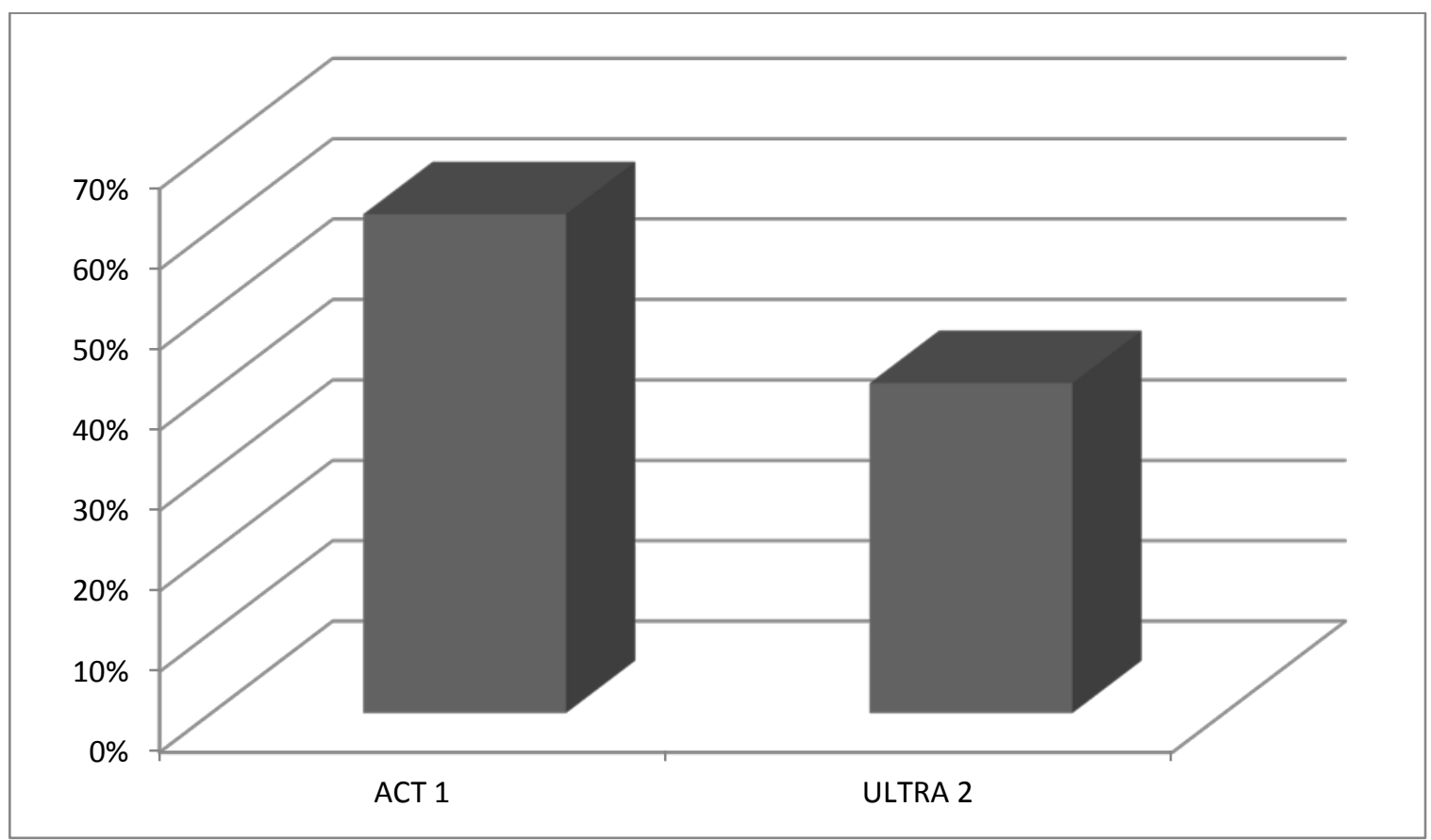




\section{References}

1. Greenberg GR, Feagan BG, Martin F, Sutherland LR, Thomson AB, Williams CN, Nilsson LG, Persson T: Oral budesonide as maintenance treatment for Crohn's disease: a placebo-controlled, dose-ranging study. Canadian Inflammatory Bowel Disease Study Group. Gastroenterology 1996;110:45-51.

2. Peyrin-Biroulet L, Lemann M: Review article: remission rates achievable by current therapies for inflammatory bowel disease. Alimentary Pharmacology \& Therapeutics 2011;33:870-879.

3. Colombel JF, Rutgeerts P, Reinisch W, Esser D, Wang YX, Lang YH, Marano CW, Strauss R, Oddens BJ, Feagan BG, et al: Early Mucosal Healing With Infliximab Is Associated With Improved Long-term Clinical Outcomes in Ulcerative Colitis. Gastroenterology 2011;141:1194-1201.

4. De Cruz P, Kamm MA, Prideaux L, Allen PB, Moore G: Mucosal healing in Crohn's disease: A systematic review. Inflamm Bowel Dis. 2012;26:22977.

5. Feagan BG, Lemann M, Befrits R, Connell W, D'Haens G, Ghosh S, Michetti P, Ochsenkuhn T, Panaccione R, Schreiber, et al: Recommendations for the treatment of Crohn's disease with tumor necrosis factor antagonists: An expert consensus report. Inflamm Bowel Dis. $2012 ; 18: 152-160$.

6. Pineton de Chambrun G, Peyrin-Biroulet L, Lemann M, Colombel JF: Clinical implications of mucosal healing for the management of IBD. Nat Rev Gastroenterol Hepatol. 2010;7:15-29.

7. Fefferman DS, Farrell RJ: Endoscopy in inflammatory bowel disease; Indications, surveillance, and use in clinical practice. Clinical Gastroenterology and Hepatology 2005;3:11-24. 
8. Sandborn WJ, Feagan BG, Hanauer SB, Lochs H, Lofberg R, Modigliani R, Present

DH, Rutgeerts P, Scholmerich J, Stange EF, et al: A review of activity indices and efficacy Endpoints for clinical trials of medical therapy in adults with Crohn's disease. Gastroenterology 2002;122:512-530.

9. Rutgeerts P, Van Assche G, Sandborn WJ, Wolf DC, Geboes K, Colombel JF, Reinisch W, Kumar A, Lazar A, Camez A, et al: Adalimumab Induces and Maintains Mucosal Healing in Patients With Crohn's Disease: Data From the EXTEND Trial. Gastroenterology 2012;142:1102-1111.

10. Rutgeerts P, Feagan BG, Lichtenstein GR, Mayer LF, Schreiber S, Colombel JF, Rachmilewitz D, Wolf DC, Olson A, Bao WH, et al: Comparison of scheduled and episodic treatment strategies of infliximab in Crohn's disease. Gastroenterology 2004;126:402-413.

11. Schnitzler F, Fidder H, Ferrante M, Noman M, Arijs I, Van Assche G, Hoffman I, Van Steen K, Vermeire S, Rutgeerts P: Mucosal Healing Predicts Long-term Outcome of Maintenance Therapy with Infliximab in Crohn's Disease. Inflamm Bowel Dis. 2009;15:12951301.

12. D'Haens G, Sandborn WJ, Feagan BG, Geboes K, Hanauer SB, Irvine EJ, Lemann M, Marteau P, Rutgeerts P, Scholmerich J, et al: A review of activity indices and efficacy end points for clinical trials of medical therapy in adults with ulcerative colitis. Gastroenterology 2007;132:763-786.

13. Mary JY, Modigliani R: Development and validation of an endoscopic index of the severity for Crohn's disease: a prospective multicentre study. Groupe d'Etudes Therapeutiques des Affections Inflammatoires du Tube Digestif (GETAID). Gut 1989;30:983-989.

14. Daperno M, D'Haens G, Van Assche G, Baert F, Bulois P, Maunoury V, Sostegni R, Rocca R, Pera A, Gevers A, et al: Development and validation of a new, simplified 
endoscopic activity score for Crohn's disease: the SES-CD. Gastrointestinal Endoscopy 2004;60:505-512.

15. Rutgeerts P, Geboes K, Vantrappen G, Beyls J, Kerremans R, Hiele M: Predictability of the postoperative course of Crohn's disease. Gastroenterology 1990;99:956-963.

16. Hebuterne X, Lemann M, Bouhnik Y, Dewit O, Dupas JL, Mross M, D'Haens G, Mitchev K, Ernault E, Vermeire S, et al: Endoscopic improvement of mucosal lesions in patients with moderate to severe ileocolonic Crohn's disease following treatment with certolizumab pegol. Gut 2012;23:23.

17. Efthymiou A, Viazis N, Mantzaris G, Papadimitriou N, Tzourmakliotis D, Raptis S, Karamanolis DG: Does clinical response correlate with mucosal healing in patients with Crohn's disease of the small bowel? A prospective, case-series study using wireless capsule endoscopy. Inflamm Bowel Dis. 2008;14:1542-1547.

18. Gal E, Geller A, Fraser G, Levi Z, Niv Y: Assessment and validation of the new capsule endoscopy Crohn's disease activity index (CECDAI). Digestive Diseases and Sciences 2008;53:1933-7.

19. Truelove SC, Witts LJ: Cortisone in ulcerative colitis; final report on a therapeutic trial. British medical journal 1955;2:1041-1048.

20. Feagan BG, Greenberg GR, Wild G, Fedorak RN, Pare P, McDonald JWD, Dube R, Cohen A, Steinhart AH, Landau, S, et al: Treatment of ulcerative colitis with a humanized antibody to the alpha(4)beta(7) integrin. New England Journal of Medicine 2005;352:24992507.

21. Schroeder KW, Tremaine WJ, Ilstrup DM: Coated oral 5-aminosalicylic acid therapy for mildly to moderately active ulcerative-colitis. A randomized study. New England Journal of Medicine 1987;317:1625-1629. 
22. Travis SPL, Schnell D, Krzeski P, Abreu MT, Altman DG, Colombel JF, Feagan BG, Hanauer SB, Lemann M, Lichtenstein GR, et al: Developing an instrument to assess the endoscopic severity of ulcerative colitis: the Ulcerative Colitis Endoscopic Index of Severity (UCEIS). Gut 2012;61:535-342.

23. Hanauer SB, Feagan BG, Lichtenstein GR, Mayer LF, Schreiber S, Colombel JF, Rachmilewitz D, Wolf DC, Olson A, Bao WH, et al: Maintenance infliximab for Crohn's disease: the ACCENT I randomised trial. Lancet 2002;359:1541-1549.

24. Colombel JF, Sandborn WJ, Reinisch W, Mantzaris GJ, Kornbluth A, Rachmilewitz D, Lichtiger S, D'Haens G, Diamond RH, Broussard DL, et al: Infliximab, Azathioprine, or Combination Therapy for Crohn's Disease. New England Journal of Medicine 2010;362:1383-1395.

25. Rutgeerts P, Sandborn WJ, Feagan BG, Reinisch W, Olson A, Johanns J, Travers S, Rachmilewitz D, Hanauer SB, Lichtenstein GR, et al: Infliximab for induction and maintenance therapy for ulcerative colitis. New England Journal of Medicine 2005;353:24622476.

26. Sandborn WJ, Colombel JF, Reinisch W, Feagan BG, Rachmilewitz D, Olson A, Johanns J, Travers S, Present D, Sands BE, et al: Infliximab induces and maintains mucosal healing in ulcerative colitis patients: The ACT trials. American Journal of Gastroenterology 2005;100:S310-S.

27. Afif W, Leighton JA, Hanauer SB, Loftus EV, Faubion WA, Pardi DS, Tremaine WJ, Krane SV, Bruining DH, Cohen RD, et al: Open-Label Study of Adalimumab in Patients with Ulcerative Colitis Including Those with Prior Loss of Response or Intolerance to Infliximab. Inflamm Bowel Dis. 2009;15:1302-1307.

28. Sandborn WJ, van Assche G, Reinisch W, Colombel JF, D'Haens G, Wolf DC, Kron M, Tighe MB, Lazar A, Thakkar RB: Adalimumab Induces and Maintains Clinical Remission 
in Patients With Moderate-to-Severe Ulcerative Colitis. Gastroenterology 2012;142:257U150.

29. Rutgeerts P, Diamond RH, Bala M, Olson A, Lichtenstein GR, Bao WH, Patel K, Wolf DC, Safdi M, Colombel JF, et al: Scheduled maintenance treatment with infliximab is superior to episodic treatment for the healing of mucosal ulceration associated with Crohn's disease. Gastrointestinal Endoscopy 2006;63:433-442.

30. D'Haens G, Baert F, van Assche G, Caenepeel P, Vergauwe P, Tuynman H, De Vos M, van Deventer S, Stitt L, Donner A, et al: Early combined immunosuppression or conventional management in patients with newly diagnosed Crohn's disease: an open randomised trial. Lancet 2008;371:660-667.

31. Regueiro M, Schraut W, Baidoo L, Kip KE, Sepulveda AR, Pesci M, Harrison J, Plevy SE, et al: Infliximab Prevents Crohn's Disease Recurrence After Ileal Resection. Gastroenterology 2009;136:441-450.

32. D'Haens G, Noman M, Baert F, Hiele M, Van Assche G, Daperno M: Endoscopic healing after infliximab treatment for Crohn's disease provides a longer time to relapse. Gastroenterology 2002;122:A-100.

33. Baert F, Moortgat L, Van Assche G, Caenepeel P, Vergauwe P, De Vos M, Stokkers P, Hommes D, Rutgeerts P, Vermeire S, et al: Mucosal Healing Predicts Sustained Clinical Remission in Patients With Early-Stage Crohn's Disease. Gastroenterology 2010;138:463468.

34. Sorrentino D, Paviotti A, Terrosu G, Avellini C, Geraci M, Zarifi D: Low-Dose Maintenance Therapy With Infliximab Prevents Postsurgical Recurrence of Crohn's Disease. Clinical Gastroenterology and Hepatology 2010;8:591-599. 
35. Wright R, Truelove SR. Serial rectal biopsy in ulcerative colitis during the course of a controlled therapeutic trial of various diets. The American journal of digestive diseases 1966;11:847-857.

36. Peyrin-Biroulet L, Ferrante M, Magro F, Campbell S, Franchimont D, Fidder H, Strid H, Ardizzone S, Veereman-Wauters G, Chevaux JB, et al: Results from the 2nd Scientific Workshop of the ECCO (I): Impact of mucosal healing on the course of inflammatory bowel disease. Journal of Crohns \& Colitis 2011;5:477-483.

37. Ardizzone S, Cassinotti A, Duca P, Mazzali C, Penati C, Manes G, Marmo R, Massari A, Molteni P, Maconi G, et al: Mucosal Healing Predicts Late Outcomes After the First Course of Corticosteroids for Newly Diagnosed Ulcerative Colitis. Clinical Gastroenterology and Hepatology 2011;9:483-U117.

38. Allez M, Lemann M, Bonnet J, Cattan P, Jian R, Modigliani R: Long term outcome of patients with active Crohn's disease exhibiting extensive and deep ulcerations at Colonoscopy. American Journal of Gastroenterology 2002;97:947-953.

39. Froslie KF, Jahnsen J, Moum BA, Vatn MH, IBSEN group: Mucosal healing in inflammatory bowel disease: Results from a Norwegian population-based cohort. Gastroenterology 2007;133:412-422.

40. Ferrante M, Vermeire S, Fidder H, Schnitzler F, Noman M, Van Assche G, De Hertogh G, hoffman I, D'Hoore A, van Steen K, et al: Long-term outcome after infliximab for refractory ulcerative colitis. Journal of Crohns \& Colitis 2008;2:219-225.

41. Rutter M, Saunders B, Wilkinson K, Rumbles S, Schofield G, Kamm M, Williams C, Price A, Talbot I, Forbes A: Severity of inflammation is a risk factor for colorectal neoplasia in ulcerative colitis. Gastroenterology 2004;126:451-459. 
42. Rutter MD, Saunders BP, Wilkinson KH, Rumbles S, Schofield G, Kamm MA, Williams CB, Price AB, Talbot IC, Forbes A: Cancer surveillance in longstanding ulcerative colitis: endoscopic appearances help predict cancer risk. Gut 2004;53:1813-1816.

43. Rubin DT, Rothe JA et al: Increased inflammatory activity is an independent risk factor for dysplasia and colorectal cancer in ulcerative colitis: A case-control analysis with blinded prospective pathology review. Gastroenterology 2006;130:A2.

44. Gupta RB, Harpaz N, Itzkowitz S, Hossain S, Matula S, Kornbluth A, Bodian C, Ullman T: Histologic inflammation is a risk factor for progression to colorectal neoplasia in ulcerative colitis: a cohort study. Gastroenterology 2007;133:1099-1105. 